Egyptian J. of Nutrition Vol. XXXIV No. 3 (2019)

\title{
Effect of irradiated pistachio and walnuts enriched-diet on biochemical aspects in rats
}

\author{
Ayat L. K. Soude ${ }^{1}$; Hania F. G. El-Neily ${ }^{1}$ \\ and Ashraf A. Abd El-Megeid ${ }^{2}$
}

1- Food irradiation Department, Industrial Irradiation Division, National Center for Radiation Research and Technology, Cairo, Egypt. 2- Nutrition and Food Science Department, Faculty of Home Economics, Helwan University, Cairo, Egypt.

\begin{abstract}
The present study aims to evaluate effect of irradiationatdoses $6 \mathrm{kGy}$ and $10 \mathrm{kGy}$ on chemical and biochemical parameters of sometypes ofnuts including pistachio (Pistachiavera L.) and walnuts (JuglansregiaL.) 70albinorats used in this study, the rats divided into 7 groups as following: Group (1): fed on basal diet, as a control group. Group (2): fed on basal diet containing unirradiated pistachio. Groups (3 and 4): fed on diets containing the irradiated pistachio on 6 and 10kGy, respectively. Group (5): fed on basal diet containing un-irradiated walnut. Groups (6 and 7): fed on diets containing the irradiated walnut on 6 and $10 \mathrm{kGy}$, respectively for 8 weeks. The statistical analysis of irradiated pistachio and walnut at dose 6 and $10 \mathrm{kGy}$ at zero time and storage for 6 months showed no significant difference in protein, moisture, ash and lipid. The biochemical performance showed non-significant effect on organs weight, total cholesterol, triacylglycerol's, high density lipoproteincholesterol (HDL-c), low density lipoprotein-cholesterol (LDL-C), blood hemoglobin, glucose, serum alanine amino transferase (ALT), serum
\end{abstract}




\section{Ayat L. K. Soude; Hania F. G. El-Neily and Ashraf A. Abd El-Megeid}

aspartate amino transferase (AST), liver superoxide dismutase (SOD), liver glutathione peroxidase (GPX) and liver catalase in groups applied doses of non-irradiated or irradiated pistachio and walnut, as compared to control group which fed on basal diet, while serum alanine amino transferase (ALT) which showed increased in untreatedpistachio and there were significant increase in antioxidant enzymes at all groups.

\section{Introduction}

Pistachio (Pistachiavera L.) belongs to Anacardiacea family being one of the most important edible nuts(Tomaino et al.,2010). The tendency toward consumption of pistachio nuts has been increased due to their nutrient contents such as sterols, vitamins, minerals, fatty acids, phenolic compounds, protein and dietary fiber. Pistachio nuts contain about $50 \%$ oil, an oil rich in oleicand linoleic acids, which provides important therapeutically effects. Oleic acid is an important monounsaturated fatty acid that helps in reducing triglycerides, low-density lipoproteins (LDL), total cholesterol and glycemic index. In addition, oleic acid is responsible for the increase of stability and reduction of oxidation in vegetable oils (Kamazani et al., 2015).

During the drying process, nuts can undergo undesirable reactions (especially rancidity) which cause degradation of quality, because of the odd colors and flavors formed;the major oxidative reactions in dried foods are due to peroxidation of lipids. Lipid oxidation in foods is associated almost exclusively with unsaturated fatty acids and it is often autocatalytic, with oxidation products themselves catalyzing the reaction so that the rate increases. The 


\section{Egyptian J. of Nutrition Vol. XXXIV No. 3 (2019)}

pistachio is a nut with a high lipid content and very rich in unsaturated fatty acids; this makes pistachio nuts very sensitive product owing to rancidity (Kashani et al., 2008).

Pistachio green hull $(\mathrm{PGH})$ is a rich source of phenolic compounds with high antioxidant activity. Gallic acid is a predominate compound of $(\mathrm{PGH})$ and can scavenge free radicals, chelating metals and reducing tocopherol radicals (Aliet al., 2018).

Walnuts (JuglansregiaL.) are widely distributed all over the world. Walnuts are receiving increasing interest as a healthy foodstuff because their regular consumption has been reported to decrease the risk of coronary heart disease. Therefore, walnuts can be utilized as ingredients of many foodstuffs such as bakery products to enhance the nutrition value and sensory properties of the final product(Xiaoyingand Yufei 2012).

Many beneficial effects on human health have been related to walnut consumption and attributed largely to oil composition, such as prevention of cardiovascular diseases, type 2 diabetes in women, and cholesterol increases. Walnut oil is predominantly composed of polyunsaturated fatty acids (PUFA), mainly omega6 linoleic acid, and omega3 linolenic acid in contrast to other nuts that they have high content of monounsaturated fatty acids (MUFA)(Miltiadisand Eleni 2015).

English walnuts have been reported to be an excellent source of antioxidants(Jacki et al., 2011).Walnut is rich in polyphenols and contains numerous ellagitannins, walnut polyphenol not only has antioxidant and anti-inflammatory activity but improves interneuronal signaling and increases neurogenesis(Dandan et al., 2014). 


\section{Ayat L. K. Soude; Hania F. G. El-Neily and Ashraf A. Abd El-Megeid}

Food irradiation has been recognized and regulated as an effective food processing technology in many countries being able to destroy or reduce ubiquitous pests and pathogens that contaminate raw foods (Diehl 1981). Radiation processing is well established as a physical, non-thermal method to preserve various food products that involves the exposure of food products (raw or processed) to ionizing or non-ionizing radiation (Antonio et al., 2012).Irradiation can also influence the levels of antioxidants/phytochemicals in plant products(Behgar et al., 2011).

Gamma radiation, more energetic than X-rays, is used from sources of radioactive isotopes, cesium-137 or cobalt-60, and it is identified by the World Health Organization as a food preservation technique that improves food safety without altering the toxicological, biological or nutritional quality of the food (Farkas and MohácsiFarkas2011).

Therefore, the present study was carried out to assess the effects of diet containing untreated and treated pistachio and walnuts on healthy rats.

\section{Material and methods}

\section{Material}

- Pistachio (Pistachiavera L.), Walnuts (JuglansregiaL.), sucrose, starch and corn oil were obtained from the local market, Cairo, Egypt.

- Casein, all vitamins, minerals, cellulose, L -Cystine and choline chloride were obtained from El-Gomhoriya company, Cairo, Egypt.

- Kits: kits used to determine hemoglobin, glucose, serumaspartate amino transferase (AST)serum alanine amino transferase (ALT).cholesterol, triglycerides; HDL-C and antioxidant enzymes 
Egyptian J. of Nutrition Vol. XXXIV No. 3 (2019)

including (malonaldehyed, liver glutathione peroxidase (GPX), Catalase andliver superoxide dismutase (SOD) were obtained from Gama tread Company, Cairo, Egypt.

\section{Methods}

y Irradiation treatment

Pistachio (Pistachiavera L.) and Walnuts (JuglansregiaL.) were packed in polyethylene bags, and sealed by heat. Each bag contained about $200 \mathrm{~g}$. they were subjected $y$ Irradiation from $\mathrm{Co}^{60}$ at National Center for Radiation Research and Technology at Nasr City, Cairo Egypt. The facility used was Gamma Chamber 400 A, Co-60 facility of India. The doses applied were 6 and $10 \mathrm{kGy}$ delivered at dose rate of $1.606 \mathrm{kGy} / \mathrm{h}$ as calibrated using small pieces of radiochromic film (Maclaughlin et al., 1985) at the time of experimentation. The samples were stored at $5^{\circ} \mathrm{C}$ until used.

\section{Chemical composition of pistachio and walnuts}

Moisture content, crude fat, crude protein, ash contentofpistachio and walnuts,were determined according to the method described by the (A.O.A.C., 2003).

The fatty acids composition were determined as the method described by (Hamilton and Hamilton, 1993).

\section{Diet preparation:}

The diets were prepared by using untreated and treated (pistachio and walnut) with irradiation. The diets were prepared according to (Reeves et al., 1993), the salt mixture was prepared according to (Hegestedet al., 1941) and the vitamin mixture was prepared according to (A.O.A.C. 2003). 


\section{Ayat L. K. Soude; Hania F. G. El-Neily and Ashraf A. Abd El-Megeid}

\section{Experimental rats}

Seventy male albino rats, Sprague-Dawley strain, with an initial weight of about $80 \pm 5 \mathrm{~g}$ were used in this study. They were obtained from animal house of National Center for Radiation Research and Technology, Atomic Energy Authority, Cairo, Egypt. The animals were housed individually in plastic cages with wire mesh bottoms at a room temperature of $22-25^{\circ} \mathrm{C}$ and $60 \pm 5 \%$ relative humidity, with a photoperiod of $12 \mathrm{~h}$ and water for eight week. Groups of ten rats were then assigned to receive one of seven experimental diets (i.e. control, untreated nuts and treated nuts with 6 and $10 \mathrm{kGy}$ irradiation) pistachio and walnut, alongside casein diet. All animals will be free access to feed and water on based diet for one week for adaptation. After this week, the rats divided into seven groups as the following: group 1 fed on basal diet as a control group, group 2, 3 and 4 were feed on untreated pistachio and treated pistachio with 6 and 10 kGy, respectively. Group 5, 6 and 7 were feed on untreated walnut and treated walnut with 6 and $10 \mathrm{kGy}$, respectively.

During the experimental period (6 week), the diets consumed and body weights were recorded every week. At the end of the experiment period, the animals were fasted overnight, then the rats were anaesthetized and sacrificed, and blood samples were collected from the aorta. The blood samples were centrifuged and serum was separated to estimate some biochemical parameters, i.e. Serum cholesterol (Richmond, 1973), triglycerides (Stein, 1987), highdensity lipoprotein-cholesterol HDL-c (Firdewald et al., 1972), low and very low density lipoprotein-cholesterol LDL-c and VLDL-C (Firdewald et al, 1972), glucose(Young, 2001), aspartate amino transferase (AST) and alanine amino transferase (ALT) (Young, 1990).Hemoglobin were estimated according to (Dacia and Lewis. 
Egyptian J. of Nutrition Vol. XXXIV No. 3 (2019)

1985).Liver and kidney were separated from each rat and weighted to calculate organs to body weight \%.

\section{Determination of antioxidant enzymes}

Superoxide dismutases (SODs) are metabolio enzymes that catalyze the dismutation of the superoxide anion to molecular oxygen and hydrogen peroxide and thus forma crucial part of the cellular antioxidant defense mechanism (Nishikimiet al., 1972).

Cellular glutathione peroxidase (GPs) is a member of a family of GPx enzyme whose function is to detoxify peroxides in the cell. The GPx enzymes play a critical role in protecting the cell from free radical damage, particularly lipid peroxidation (Pagliaand Valentine 1967).

Catalase is antioxidant enzyme that is present in the most aerobic cells. Its serves as one of the body's defense systems against $\mathrm{H}_{2} \mathrm{O}_{2}$ a strong oxidant that can cause intracellular damage (Aebi, 1984).

The data obtained was analyzed statistically for standard deviation and one-way ANOVA test according to (Duncan, 1955).

\section{Results and Discussion}

Effect of radiation processing with storage on chemical composition of Pistachio and Walnut.

The effect of radiation processing at (6 and $10 \mathrm{kGy}$ ) on the mean values of moisture, ash, crude protein, and crude fat of pistachio and walnut in zero time and after storage for 6 months presented in Tables (1 and 2). 


\section{Ayat L. K. Soude; Hania F. G. El-Neily and Ashraf A. Abd El-Megeid}

\section{Pistachio}

The variation of moisture, ash, crude protein and crude fat of pistachio treated with irradiation at zero time and after storage for six months were studied and the results are presented in Tables (1). The mean values ofmoisture content of pistachio showed nonsignificant changes after treated with irradiation at dose $(6$ and 10 kGy). Ash content of pistachio, which treated with irradiation at dose (10kGy), showed significant decreasethan the control sample (at zero time). The other nutrients (protein and lipid) recorded non-significant changes with the two dosage of irradiation, as compared to the control sample at zero time.

Results in this Table indicated that, non-significant changes in the chemical composition of pistachio which treated with irradiation at two doses with storage, while the content of ash in pistachio, which treated with irradiation at dose $10 \mathrm{kGy}$, decreased, as compared to the control sample. (Mahfouz, 2014) resulted that irradiation doses of 1,2 and $3 \mathrm{kGy}$ of gamma irradiation showed not substantially affected in contents of moisture, proteins, lipid, and ash, with respect to the pistachio control samples.

\section{Walnut}

The mean values of moisture, ash, crude protein and crude fat of walnut treated with irradiation with doses 6 and $10 \mathrm{kGy}$ at zero time and after storage for six months were studied and the results are presented in Table (2).The data showed that, at zero time, nonsignificant differences were observed in moisture, ash and protein in un-treated walnut and treated with irradiation at (6 and $10 \mathrm{kGy}$ ), while total lipid in this type of nuts which treated at dose $10 \mathrm{kGy}$, it increased, as compared to the control sample.Storage for 6 months 
Egyptian J. of Nutrition Vol. XXXIV No. 3 (2019)

presented untreated and treated walnut with irradiation at (6 and10 kGy) induced non-significant changes in moisture, ash and protein, while total lipid increased significantly in walnut which treated with 6 and $10 \mathrm{kGy}$, as compared to the control sample.Generally, there was non-significant effect in moisture at zero time but there was significant effect in moisture at storage period may be due to the humidity from storage condition.

The average values for protein and fat were $18.1 \%$ and $58.2 \%$ in walnut respectively (Ferhad et al., 2010)and(Sza-Tao and sathe ,2000)reported that, walnut contained $16.66 \%$ protein and $66.90 \%$ lipids on a dry weight basis. Two walnut cultivars were examined as fresh samples and under storage at $8^{\circ} \mathrm{C}$ for two months. The oil content is the lowest in fresh samples of all the cultivars. At this stage, the oil content of 'Chandler' was lower than of the others. The results show significant difference between the two ways of drying for the Hungarian cultivars $(P<0.05)$ (Konya et al., 2015).

Fatty acids composition of Pistachio and Walnut treated with irradiation at zero time and after storage period:

The fatty acids composition of two types of nuts sample exposed to different doses of irradiation are presented in Tables (3 and 4).

\section{Pistachio}

The data in Table (3) indicated that, at zero time the control pistachio contain $13.09 \%$ saturated fatty acids (SFA) (palmitic acid) that was the major saturated fatty acid. Treating pistachio sample with irradiation led to decrease in palmitic acid by about $17.2 \%$ at $6 \mathrm{kGy}$ and decreased at $10 \mathrm{kGy}$ by $20.01 \%$.Monounsaturated fatty 


\section{Ayat L. K. Soude; Hania F. G. El-Neily and Ashraf A. Abd El-Megeid}

acid (MUFA) (oliec acid) of raw sample was $69.97 \%$ that was the major (MUFA). The data in this table showed that there is change in oleic acid at $6 \mathrm{kGy}$ increased by $1.7 \%$ and at $10 \mathrm{kGydecreased} \mathrm{by}$ $0.7 \%$.Polyunsaturated fatty acids (PUFA) (linoleic acid) of control sample was $16.92 \%$ that the major (PUFA). The data indicated that the linoleic acid increased by about (6.6\%and $12.29 \%)$ at $6 \mathrm{kGy}$ and $10 \mathrm{kGy}$, respectively, than that of that control. After 6 months palmitic acid increased by about $5.4 \%$; oliec acid decreased by $0.4 \%$, and linoliec acid were increased by $3.3 \%$, when treated pistachio with irradiation at $6 \mathrm{kGy}$, while at 10kGy the palmitic acid, olic acid and linoliec acid decreased by about (1.0\%, 9.0\% and $16.7 \%)$, respectively in pistachio, as compared to the control sample.

Mahfouz(2014)indicated that the highest used dose (3kGy) to pistachio samples slightly decreased the fatty acid content.

\section{Walnut}

The data in Table (4) indicated that, at zero time the control walnut contain $15.7 \%$ saturated fatty acids (SFA) (palmitic acid and stearic acid) the major saturated fatty acid was palmitic acid $(11.59 \%)$ followed by and stearic acid was $(4.13 \%)$. Treating walnut sample with irradiation decrease in palmitic acid change by $35.97 \%$ at $6 \mathrm{kGy}$ and increased at $10 \mathrm{kGy}$ by $9.4 \%$ ).Monounsaturated fatty acid (MUFA) (Oliec acid) of raw sample was $23.33 \%$ that was the major (MUFA). Oleic acid decreased by $31.67 \%$ at $6 \mathrm{kGy}$ and by $0.8 \%$ at 10 kGy.Polyunsaturated fatty acids (PUFA) (linoleic acid) of control sample was $50.16 \%$ that the major (PUFA). The data indicated that the linoleic acid increased by $28.42 \%$ at $6 \mathrm{kGy}$ and decreased by $2.3 \%$ at $10 \mathrm{kGy}$. 
Egyptian J. of Nutrition Vol. XXXIV No. 3 (2019)

After storage for 6 months saturated fatty acids decreased in walnut with irradiation, while unsaturated fatty acids increased. Stamatios and Michael (2009) determined treated and untreated walnuts with irradiation doses at 1.0, 1.5, 3.0, 5.0 and 7.0 kGy. The fatty acids determined, stearic and palmitic acids concentration increased while oleic acid decreased with irradiation dose. Polyunsaturated fatty acids were unaffected by irradiation.

Umit et al., (2011)The concentration of total saturated fatty acids increased while total mono unsaturated and total polyunsaturated fatty acids decreased in hazelnut, walnut almonds and pistachio nut which treated with 1, 3, 5 and 7 kGy.

Vassilia et al., (2015)GC-FID results showed that SFA increased and MUFA and PUFA decreased with the increase of irradiation dose (5, 10, $13 \mathrm{KGy}$ dose). Moreover, MUFA/SFA and PUFA/SFA ratios decreased $(P<0.05)$ compared to control samples.

Biological analysis for rats feed on diet contain untreated and treated pistachio and walnutwith irradiation

\section{Relative organs weight of rats}

\section{Pistachio}

The mean value $\pm S D$ of relative organs weights of rats fed on diets containing un-treated and treated pistachio with irradiation at dose (6 \& $10 \mathrm{kGy}$ ) showed in Table (5). The results indicated that, all organs weights, recorded non-significant changes in-group of rats fed on diet containing untreated and treated pistachio with two dosage of irradiation, as compared to the control group, which fed on control diet onlyexcept the mean value of spleen, which recorded significantincrease. 


\section{Ayat L. K. Soude; Hania F. G. El-Neily and Ashraf A. Abd El-Megeid}

\section{Walnut}

The mean value $\pm S D$ of relative organs weight of rats fed on diets containing un-treated and treated walnut with irradiation at dose (6 \& 10 kGy) showed in Table (6). The mean values of heart and liver weight showed non-significant changes in the group fed on untreated walnut,while the weight oftests and kidney recorded significant increase, as compared to the control (fed on basal diet only). The two treated groups with irradiation with dose (6 and $10 \mathrm{kGy}$ ) showed significant increase in heart, spleen and kidney weights, while liver and tests recorded non-significant differences, as compared to the group fed on untreated walnut

Effect of diet containing untreated and treated pistachio and walnut on somebiochemical analysis of healthy rats.

\section{Pistachio}

The effect of enriched diet with untreated and treated pistachio with irradiation at (6 \& $10 \mathrm{kGy})$ on hemoglobin, glucose, AST and ALT of healthy rats presented in Table (7).The results in this Table showed significant differences in the mean values of hemoglobin, glucose, AST and ALT between the groups fed on diet containing untreated pistachio, as compared to control group.Treated pistachiowith irradiation at dose 6 and $10 \mathrm{kGy}$, led to significant decrease in the mean value of hemoglobin and glucose levels, as compared to untreated pistachio. The data in this Table showed significant decrease in AST and ALT enzymes with high dose from irradiation, as compared to the control group (fed on untreated pistachio). 
Egyptian J. of Nutrition Vol. XXXIV No. 3 (2019)

\section{Walnut}

The effect of enriched diet with untreated and treated walnut with irradiation at (6 \& $10 \mathrm{kGy}$ ) on hemoglobin, glucose, AST and ALT of basil diet rats presented in Table (8). Non-significant changes in all tested parameters was observed between the groups fed on diet containing (un-treated or treated walnut with irradiation at dose 6 and $10 \mathrm{kGy}$ ), except AST and ALT enzymes in the group of rats which treated with $10 \mathrm{kGy}$, as compared to the control group fed onbasal diet only.

In this respect (Jiang et al.,2002) reported that, the Nurses' Health Study showed in 83,818 healthy women that eating $140 \mathrm{~g}$ of nuts per week was related to a significant lower DMT2-risk compared to non-consumers. This result was inter alia attributed to the low glycemic index of nuts and their high fiber and magnesium content. In addition, recent studies with 135,956 women confirmed an association between increased walnut consumption (> $56 \mathrm{~g} / \mathrm{week}$ ) and a lower incidence (15\%) for DMT2 (Pan and Manson 2013).

Kochar et al. (2010) observed no effect of nut consumption on the DMT2-risk in 20,224 male subjects of the Physician's Health Study.

The responsible mechanisms mediated by nut consumption which cause a reduction of the DMT2-riskare not yet fully understood. A modulation of the adiponectine concentration appears conceivable (Aronis et al., 2012).The protein, formed by fat-laden adipocytes, is involved in the regulation of appetite and inverse associated with the DMT2-risk (Heidemann et al., 2008). 


\section{Ayat L. K. Soude; Hania F. G. El-Neily and Ashraf A. Abd El-Megeid}

It is also possible that an increase in insulin sensitivity results from the arginine and zinc content of the nuts, which stimulate both insulin secretion and the receptor tyrosine kinase and thereby increase the insulin sensitivity of the cells. In addition, a reduced postprandial glycemic response mediated by nut consumption and a significantly higher release of satiety hormones (PYY) may also contribute to the prevention of DMT2 (Reis et al., 2012).

Nuts are highly nutritious foods rich in unsaturated fatty acids, fiber, vitamins, minerals and some bioactive substances, such as phenolic antioxidants and phytosterols(Bao et al., 2013 ) and due to these wholesome benefits, individuals living with liver disease are usually advised to include nuts in their diet (Han et al., 2014).The improvement in liver enzymes in treated diabetic rats with some nuts may be related to the antioxidant properties of these nuts, which have, scavenge free radicals and thereby may protect cells from oxidative stress.

Nazirogluet al., (1999)reported that, administered vitamin E has protective effects against $\mathrm{CCl}_{4}$-induced chronic liver damage and cirrhosis as evidenced by biochemical data and conventional histological examination.

Effect of diet containing untreated and treated pistachio and walnut on lipid profile of healthy rats:

\section{Pistachio}

The effect of feeding rats ondiet containing untreated and treated pistachio, on lipid profile of healthy rats presented in Table (9).The results indicated that, non-significant changes in all parameters of lipid profile in rats fed on diet containing untreated 


\section{Egyptian J. of Nutrition Vol. XXXIV No. 3 (2019)}

pistachio, as compared to healthy rats fed on basal diet, except triacylglycerol which showed significant increase. On the other hand, feeding rats on diets containing pistachio, which treated with irradiation (6 \& $10 \mathrm{kGy}$ ) caused non-significant differences in serum cholesterol, triglyceride, HDL-C and LDL-c, as compared to the group fed on diet containing untreated pistachio. In this respect, (Nur et al,. 2007)reported that, consumption of pistachio as $20 \%$ of daily caloric intake increased high-density lipoprotein (HDL) levels and decreased the ration of total cholesterol/ high density lipoprotein $T C / H D L$, compared with those not taken pistachio.

In general, all types untreated and treated nuts did not changed the lipid profile as compared to the control group, or improved the most parameters of lipid profile. In this respect, Clinical trials up to 2009 have already shown that regular nut consumption can have beneficial effects on cholesterol and triglyceride levels Subsequent studies have confirmed these effects. Several intervention studies obtained with different types of nuts (pistachios, Brazil nuts, walnuts, almonds, hazelnuts or peanuts) and consumption patterns $(30-80 \mathrm{~g} / \mathrm{d})$ in healthy individuals and subjects with hyperlipidemia showed both a reduction in total cholesterol (TC) by an average of $10.1 \%$ as well as a reduction in LDL-cholesterol (LDL-C) by an average of $8.6 \%$ (Damasceno et al., 2011 and McKiernan et al., 2010).

These effects were often attributed to the favorable fatty acid profile and the dietary fiber content of nuts. Some studies also showed an increase in HDL-cholesterol (HDL-C) as well as a decrease in triglycerides (TG) and apolipoprotein B (Apo B) (Sabate et al., 2003 and Tey et al., 2011)those results were particularly evident in people already suffering from hyperlipidemia. 


\section{Ayat L. K. Soude; Hania F. G. El-Neily and Ashraf A. Abd El-Megeid}

Another intervention study even achieved in obese participants an improvement of blood-lipid parameters, but the level of significance for this effect was only reached in subjects with hyperlipidemia (McKiernan et al., 2010).

\section{Walnut}

The result of serum cholesterol, Triacylglycerol, HDL-c and LDL-C in rats fed on basal diet, diet containing untreated walnut and diets containing irradiated walnut with (6 kGy and 10kGy) presented in Table (10). Feeding healthy rats on diet containing untreated walnut showed non-significant differences in all lipid profile, except triglyceride, which showed significant increase,and LDL-C which recorded significant decrease, as compared to healthy rats fed on basal diet. Treating healthy rats with irradiated walnut (6 and $10 \mathrm{kGy}$ ) recorded non-significant changes in total cholesterol, triglyceride, HDL-C and LDL-c, except the mean value of serum cholesterol in treated rats with irradiated walnut with $10 \mathrm{kGy}$ and LDL-c in the group which treated with irradiated walnut with 6kGy, as compared to healthy rats fed on untreated walnut.Jacki et al., (2011) reported that, walnut consumption has been associated with improvements in serum lipid profile.

The effect of untreated and treated pistachio and walnut with irradiation on antioxidant enzymes in rats

Important determinants of cellular antioxidant enzyme are the enzymes Sodium Oxide Dismutase (SOD), Catalase (CAT) and Glutathion Peroxidase (GPx), which are responsible for the elimination of Reactive Oxygen Species ROS. Because these enzymes act sequentially to remove ROS, the balance of the activity 
Egyptian J. of Nutrition Vol. XXXIV No. 3 (2019)

of these enzymes may be as critical in the defense against ROS as the activity of the enzymes alone (Boateng et al., 2016).

\section{Pistachio}

Feeding rats on diet containing treated and untreated pistachiowithirradiation on antioxidant enzymes including malonaldehyedand antioxidant enzymesof healthy rats presented in Table (11). The table showed decrease malonaldehyed significantly in the group feed with untreated pistachio, while non-significant changes in GPX, Catalase and SOD were observed, as compared to healthy rats, fed on basal diet.Treating pistachio with the two doses from irradiation (6 and $10 \mathrm{kGy}$ ) showed significant decrease in malonaldehyed, while the other antioxidant enzymes recorded significant increase with irradiation, as compared to the group feed with untreated pistachio.

Sari and Bagic (2010) who reported that, substituted saturated fat with pistachio (comprising about $20 \%$ of daily caloric intake) for a period of 4 weeks. The pistachio diet led to lower glucose, lipids, total oxidant status, and malondialdehyde, and increased superoxide dismutase.

\section{Walnut}

Data in Tables (12) revealed that, the mean values of malonaldehyed decreased significantly in the group fed on untreated walnut,while GPX and SOD showed non-significant changes, as compared to the control group.On the other hand, the mean value of catalase increased significantly in healthy rats fed on diet containing untreated walnut, as compared to control group fed on basal diet.The mean value of malonaldehyed in healthy groups, which were feed with irradiated walnut with 6 and $10 \mathrm{kGy}$, showed significant 


\section{Ayat L. K. Soude; Hania F. G. El-Neily and Ashraf A. Abd El-Megeid}

differences; on the other hand, the other antioxidant enzymes antioxidant enzymesrecorded significant increase, as compared to the group feed with untreated walnut.In this respect, (Dandan et al., 2014) stated that, walnut polyphenol (WP) significantly decreased serum total triglycerides, cholesterol and malondialdehyde (MDA) level and increased superoxide dismutase (SOD) activity. Administration of WP significantly decreased MDA level and increased SOD activity in brain tissues. The treatment of rats with alcohol and alcohol + walnut containing diet supplementation caused changes in the level of serum enzymes and (MDA) content (Bedia et al., 2015). 
Egyptian J. of Nutrition Vol. XXXIV No. 3 (2019)

(Table 1): Approximate analysis of un-treated and treated pistachio with irradiation.

\begin{tabular}{l|c|c|c|c|c|c|c|c}
\hline \multirow{2}{*}{ Radiation } & \multicolumn{4}{|c|}{ Zero time } & \multicolumn{4}{c}{ Storage (6 months) } \\
\cline { 2 - 9 } dose kGy & Moisture & Ash & Protein & Lipid & Moisture & Ash & Protein & Lipid \\
\hline \multirow{2}{*}{ Control } & $7.73^{\mathrm{b}}$ & $2.66^{\mathrm{a}}$ & $28.10^{\mathrm{a}}$ & $52.65^{\mathrm{a}}$ & $6.63^{\mathrm{a}}$ & $3.16^{\mathrm{a}}$ & $21.10^{\mathrm{a}}$ & $60.47^{\mathrm{a}}$ \\
& \pm 0.088 & \pm 0.033 & \pm 0 & \pm 1.012 & \pm 0.328 & \pm 0.33 & \pm 0 & \pm 5.567 \\
\hline \multirow{2}{*}{6 kGy } & $6.86^{\mathrm{b}}$ & $2.50^{\mathrm{ab}}$ & $28.70^{\mathrm{a}}$ & $52.03^{\mathrm{a}}$ & $3.91^{\mathrm{a}}$ & $3.50^{\mathrm{a}}$ & $19.60^{\mathrm{a}}$ & $54.67^{\mathrm{a}}$ \\
& \pm 0.120 & \pm 0.000 & \pm 0 & \pm 0.328 & \pm 1.000 & \pm 0.300 & \pm 0 & 0.338 \\
\hline \multirow{2}{*}{10 kGy } & $6.36^{\mathrm{b}}$ & $2.47 \mathrm{~b}$ & $27.50^{\mathrm{a}}$ & $52.19^{\mathrm{a}}$ & $5.93^{\mathrm{a}}$ & $2.40^{\mathrm{b}}$ & $18.20^{\mathrm{a}}$ & $54.90^{\mathrm{a}}$ \\
& \pm 0.239 & \pm 0.088 & \pm 0 & \pm 0.634 & \pm 1.517 & \pm 0.230 & \pm 0 & \pm 0.000 \\
\hline
\end{tabular}

${ }^{*}$ Data represented mean \pm standard error.

*Values at the same column with different letters are significant at $P<0.05$.

(Table 2): Approximate analysis of un-treated and treated walnut with irradiation.

\begin{tabular}{c|c|c|c|c|c|c|c|c}
\hline $\begin{array}{c}\text { Radiation } \\
\text { dose } \\
\text { kGy }\end{array}$ & \multicolumn{4}{|c|}{ Zero time } & \multicolumn{4}{c}{ Storage (6 months) } \\
\cline { 2 - 9 } & Moisture & Ash & Protein & Lipid & Moisture & Ash & Protein & Lipid \\
\hline \multirow{2}{*}{ Control } & $6.25^{\mathrm{a}}$ & $1.60^{\mathrm{a}}$ & $21.10^{\mathrm{a}}$ & $67.97^{\mathrm{a}}$ & $10.43^{\mathrm{a}}$ & $1.83^{\mathrm{a}}$ & $21.80^{\mathrm{a}}$ & $60.17^{\mathrm{c}}$ \\
& \pm 1.134 & \pm 0.100 & \pm 0 & \pm 0.233 & \pm 0.219 & \pm 0.939 & \pm 0 & \pm 0.233 \\
\hline \multirow{2}{*}{6 kGy } & $4.80^{\mathrm{a}}$ & $1.73^{\mathrm{a}}$ & $22.60^{\mathrm{a}}$ & $64.73^{\mathrm{a}}$ & $11.60^{\mathrm{a}}$ & $2.00^{\mathrm{a}}$ & $20.30^{\mathrm{a}}$ & $66.70^{\mathrm{b}}$ \\
& \pm 0.058 & \pm 0.033 & \pm 0 & \pm 1.524 & \pm 0.602 & \pm 0.306 & \pm 0 & \pm 0.000 \\
\hline \multirow{2}{*}{$10 \mathrm{kGy}$} & $4.33^{\mathrm{a}}$ & $1.80^{\mathrm{a}}$ & $22.50^{\mathrm{a}}$ & $64.13^{\mathrm{b}}$ & $11.77^{\mathrm{a}}$ & $1.43^{\mathrm{a}}$ & $22.60^{\mathrm{a}}$ & $69.80^{\mathrm{a}}$ \\
& \pm 0.333 & \pm 0.057 & \pm 0 & \pm 0.677 & \pm 0.426 & \pm 0.290 & \pm 0 & \pm 0.000 \\
\hline
\end{tabular}

*Data represented mean \pm standard error.

*Values at the same column with different letters are significant at $P<0.05$. 


\section{Ayat L. K. Soude; Hania F. G. El-Neily and Ashraf A. Abd El-Megeid}

Table (3): The percentage of fatty acids in control and irradiated pistachio at zero time and after storage for 6 months.

\begin{tabular}{l|c|c|c|c|c|c}
\hline \multicolumn{7}{c}{ Zero time } \\
\hline Fatty acid & Carbon no. & control & 6 kGy & Change\% & $10 \mathrm{kGy}$ & Change\% \\
\hline Palmitic acid & C 16:0 & 13.09 & 10.77 & -17.2 & 10.47 & -20.01 \\
\hline Oleic acid & C 18:1 & 69.97 & 71.18 & +1.7 & 70.52 & +0.7 \\
\hline Linoliec & C 18:2 & 16.92 & 18.04 & +6.6 & 19.0 & +12.29 \\
\hline \multicolumn{7}{|c|}{ Pistachio after storage for 6 months } \\
\hline Palmitic acid & C 16:0 & 9.80 & 10.33 & +5.4 & 9.7 & -1.02 \\
\hline Oleic acid & C 18:1 & 70.81 & 70.47 & -0.4 & 64.4 & -9.0 \\
\hline Linoliec & C 18:2 & 17.3 & 17.9 & -3.3 & 14.4 & -16.7 \\
\hline
\end{tabular}

Table (4): The percentage of fatty acids in control and irradiated walnut with irradiation at zero time and after storage for 6 ment

\begin{tabular}{l|c|c|c|c|c|c}
\hline \multicolumn{7}{c}{ Zero time } \\
\hline Fatty acid & Carbon no. & Control & 6 kGy & Change\% & 10 kGy & Change\% \\
\hline Palmitic acid & C 16:0 & 11.59 & 7.42 & -35.97 & 12.68 & +9.4 \\
\hline Stearic & C 18:0 & 4.13 & -- & -- & 4.17 & +0.9 \\
\hline Oleic acid & C 18:1 & 23.33 & 15.94 & -31.67 & 23.14 & -0.8 \\
\hline Linoliec & C 18:2 & 50.16 & 53.90 & +28.42 & 49.0 & -2.3 \\
\hline
\end{tabular}

Six months

\begin{tabular}{l|c|c|c|c|c|c}
\hline Palmitic acid & C 16:0 & 13.5 & 13.35 & -1.1 & 8.3 & -38.51 \\
\hline Stearic & C 18:0 & 31.96 & 26.22 & -17.95 & 21.74 & -31.97 \\
\hline Linoliec & C 18:2 & 35.6 & 38.97 & +9.46 & 45.8 & +28.65 \\
\hline Linolenic & C 18:3 & 3.0 & 3.6 & +20 & 7.9 & +163 \\
\hline
\end{tabular}


Egyptian J. of Nutrition Vol. XXXIV No. 3 (2019)

Table (5): Relative organs weight of rats fed on diet containing untreated and treated pistachio with irradiation.

\begin{tabular}{|c|c|c|c|c|c|c|}
\hline & & $\begin{array}{c}\text { Heart ( } \mathrm{g} / \\
100 \mathrm{~g} \text { body } \\
\text { weight) }\end{array}$ & $\begin{array}{c}\text { Liver ( } \mathrm{g} / \\
100 \mathrm{~g} \text { body } \\
\text { weight) }\end{array}$ & $\begin{array}{c}\text { Spleen ( } \mathrm{g} / \\
100 \mathrm{~g} \text { body } \\
\text { weight) }\end{array}$ & $\begin{array}{c}\text { Tests ( } \mathrm{g} / \\
100 \mathrm{~g} \text { body } \\
\text { weight) }\end{array}$ & $\begin{array}{c}\text { Kidney ( } \mathrm{g} / \\
100 \mathrm{~g} \text { body } \\
\text { weight) }\end{array}$ \\
\hline \multicolumn{2}{|l|}{ Basil diet } & $\begin{array}{l}0.70^{a} \\
\pm 0.01\end{array}$ & $\begin{array}{l}5.02^{\mathrm{a}} \\
\pm 0.14\end{array}$ & $\begin{array}{l}0.56^{c} \\
\pm 0.04\end{array}$ & $\begin{array}{l}1.34^{\mathrm{ab}} \\
\pm 0.08\end{array}$ & $\begin{array}{l}1.13^{\mathrm{a}} \\
\pm 0.07\end{array}$ \\
\hline \multicolumn{2}{|l|}{$\begin{array}{l}\text { untreated } \\
\text { pistachio }\end{array}$} & $\begin{array}{l}0.69^{a} \\
\pm 0.04\end{array}$ & $\begin{array}{l}4.59^{a} \\
\pm 0.14\end{array}$ & $\begin{array}{l}0.67^{a} \\
\pm 0.06\end{array}$ & $\begin{array}{l}1.75^{\mathrm{a}} \\
\pm 0.06\end{array}$ & $\begin{array}{l}1.03^{\mathrm{a}} \\
\pm 0.04\end{array}$ \\
\hline \multirow{2}{*}{ 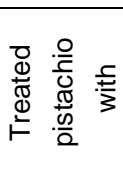 } & $\begin{array}{c}6 \\
\text { KGy }\end{array}$ & $\begin{array}{l}0.65^{\mathrm{a}} \\
\pm 0.08\end{array}$ & $\begin{array}{l}5.02^{\mathrm{a}} \\
\pm 0.27\end{array}$ & $\begin{array}{l}0.60^{\mathrm{b}} \\
\pm 0.06\end{array}$ & $\begin{array}{l}1.40^{\mathrm{b}} \\
\pm 0.04\end{array}$ & $\begin{array}{l}1.14^{\mathrm{a}} \\
\pm 0.05\end{array}$ \\
\hline & $\begin{array}{c}10 \\
\text { KGy }\end{array}$ & $\begin{array}{c}0.8^{a} \\
\pm 0.06\end{array}$ & $\begin{array}{l}4.48^{a} \\
\pm 0.15\end{array}$ & $\begin{array}{l}0.60^{\mathrm{b}} \\
\pm 0.05\end{array}$ & $\begin{array}{l}1.51^{\mathrm{a}} \\
\pm 010\end{array}$ & $\begin{array}{l}1.03^{\mathrm{a}} \\
\pm 0.04\end{array}$ \\
\hline \multicolumn{2}{|c|}{ P. value } & 0.0001 & 0.0001 & 0.0001 & 0.0001 & 0.0001 \\
\hline
\end{tabular}

*Values are expressed as means \pm SD.

*Values at the same column with different letters are significant at $\mathrm{P}<0.05$.

Table (6): Relative weight of body organs of rats feed on un-treated and treated walnu twith irradiation

\begin{tabular}{|c|c|c|c|c|c|c|}
\hline \multicolumn{2}{|c|}{$\begin{array}{c}\text { Radiation } \\
\text { doses }\end{array}$} & $\begin{array}{c}\text { Heart (g / } \\
100 \text { g body } \\
\text { weight) }\end{array}$ & $\begin{array}{c}\text { Liver (g / } \\
100 \text { g body } \\
\text { weight) }\end{array}$ & $\begin{array}{c}\text { Spleen (g / } \\
100 \text { g body } \\
\text { weight) }\end{array}$ & $\begin{array}{c}\text { Tests (g / } \\
100 \text { g body } \\
\text { weight) }\end{array}$ & $\begin{array}{c}\text { Kidney (g/ } \\
100 \mathrm{~g} \text { body } \\
\text { weight) }\end{array}$ \\
\hline \multirow{2}{*}{\multicolumn{2}{|c|}{ Basil diet }} & $0.70^{\mathrm{a}}$ & $5.02^{a}$ & $0.56^{a}$ & $1.34^{b}$ & $1.13^{c}$ \\
\hline & & \pm 0.02 & \pm 0.14 & \pm 0.04 & \pm 0.08 & \pm 0.07 \\
\hline \multirow{2}{*}{\multicolumn{2}{|c|}{$\begin{array}{l}\text { untreated } \\
\text { walnut }\end{array}$}} & $0.69^{a}$ & $4.88^{a}$ & $0.506^{b}$ & $1.81^{a}$ & $1.23^{b}$ \\
\hline & & \pm 0.0 .06 & \pm 0.21 & \pm 0.03 & \pm 0.12 & \pm 0.07 \\
\hline \multirow{4}{*}{ 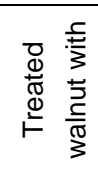 } & 6 & $0.81^{b}$ & $5.34^{a}$ & $0.58^{\mathrm{a}}$ & $1.66^{a b}$ & $1.30^{\mathrm{a}}$ \\
\hline & KGy & \pm 0.06 & \pm 0.37 & \pm 0.05 & \pm 0.09 & \pm 0.04 \\
\hline & 10 & $0.77^{a}$ & $4.89^{a}$ & $0.60^{a}$ & $1.93^{a}$ & $1.29^{a}$ \\
\hline & KGy & \pm 0.03 & \pm 0.26 & \pm 0.071 & \pm 0.16 & \pm 0.05 \\
\hline \multicolumn{2}{|c|}{ P. value } & 0.0004 & 0.581 & 0.580 & 0.013 & 0.220 \\
\hline
\end{tabular}

*Values are expressed as means \pm SD.

*Values at the same column with different letters are significant at $\mathrm{P}<0.05$. 


\section{Ayat L. K. Soude; Hania F. G. El-Neily and Ashraf A. Abd El-Megeid}

Table (7): Effect of diet containing untreated and treated pistachio on blood hemoglobin, serum glucose and liver enzymes

\begin{tabular}{|c|c|c|c|c|c|}
\hline \multicolumn{2}{|c|}{ Groups } & Hemoglobin mg/l & $\begin{array}{c}\text { Glucose } \\
\mathrm{g} / \mathrm{l}\end{array}$ & AST U/L & ALT U/L \\
\hline \multicolumn{2}{|l|}{ Basil diet } & $\begin{array}{c}15.73^{\mathrm{b}} \\
\pm 1.5\end{array}$ & $\begin{array}{c}74.22^{\mathrm{a}} \\
\pm 7.0\end{array}$ & $\begin{array}{c}90.75^{\mathrm{a}} \\
\pm 7.3\end{array}$ & $\begin{array}{l}22.16^{\mathrm{b}} \\
\pm 1.10\end{array}$ \\
\hline \multicolumn{2}{|l|}{$\begin{array}{l}\text { Untreated } \\
\text { pistachio }\end{array}$} & $\begin{array}{l}18.58^{\mathrm{a}} \\
\pm 1.14\end{array}$ & $\begin{array}{l}88.27^{b} \\
\pm 15.02\end{array}$ & $\begin{array}{l}89.00^{\mathrm{b}} \\
\pm 2.34\end{array}$ & $\begin{array}{l}21.33^{\mathrm{b}} \\
\pm 1.47\end{array}$ \\
\hline \multirow{2}{*}{ 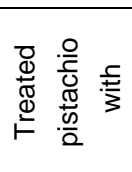 } & 6 kGy & $\begin{array}{l}14.44^{\mathrm{c}} \\
\pm 1.49\end{array}$ & $\begin{array}{l}64.00^{\mathrm{b}} \\
\pm 6.97\end{array}$ & $\begin{array}{l}90.00^{\mathrm{a}} \\
\pm 0\end{array}$ & $\begin{array}{l}25.33^{\mathrm{a}} \\
\pm 0.42\end{array}$ \\
\hline & 10 kGy & $\begin{array}{l}14.68^{\mathrm{c}} \\
\pm 1.17\end{array}$ & $\begin{array}{l}71.73^{\mathrm{a}} \\
\pm 1.17\end{array}$ & $\begin{array}{l}83.33^{c} \\
\pm 2.65\end{array}$ & $\begin{array}{l}15.50^{c} \\
\pm 0.50\end{array}$ \\
\hline \multicolumn{2}{|c|}{ PV } & 0.326 & 0.579 & 0.384 & 0.0001 \\
\hline
\end{tabular}

*Values are expressed as means \pm SD.

*Values at the same column with different letters are significant at $P<0.05$.

Table (8): Effect of diet containing untreated and treated walnut on hemoglobin, glucose and liver enzymes

\begin{tabular}{|c|c|c|c|c|c|}
\hline \multicolumn{2}{|c|}{ Groups } & Hemoglobin mg/l & Glucose $\mathrm{g} / \mathrm{l}$ & AST U/L & $A L T U / L$ \\
\hline \multirow{2}{*}{\multicolumn{2}{|c|}{ Basil diet }} & $15.73^{b}$ & $74.22^{\mathrm{ab}}$ & $91.75^{b}$ & $22.16^{\mathrm{c}}$ \\
\hline & & \pm 1.52 & \pm 7.03 & \pm 7.30 & \pm 1.10 \\
\hline \multirow{2}{*}{\multicolumn{2}{|c|}{ Untreated walnut }} & $17.46^{a}$ & $81.23^{\mathrm{b}}$ & $81.25^{\mathrm{a}}$ & $17.66^{a b}$ \\
\hline & & \pm 1.15 & \pm 10.50 & \pm 1.03 & \pm 1.17 \\
\hline \multirow{4}{*}{ 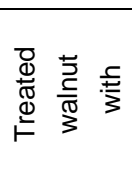 } & & $17.40^{\mathrm{a}}$ & $75.52^{c}$ & $83.00^{\mathrm{ab}}$ & $18.33^{b}$ \\
\hline & 6 kGy & \pm 0.59 & \pm 3.37 & \pm 2.00 & \pm 2.71 \\
\hline & 10 & $17.14^{\mathrm{a}}$ & $88.99^{a}$ & $80.75^{a}$ & $17.16^{b}$ \\
\hline & kGy & \pm 1.58 & \pm 4.07 & \pm 4.98 & \pm 1.77 \\
\hline \multicolumn{2}{|c|}{ PV } & 0.748 & 0.449 & 0.268 & 0.227 \\
\hline
\end{tabular}

*Values are expressed as means \pm SD.

*Values at the same column with different letters are significant at $\mathrm{P}<0.05$. 
Egyptian J. of Nutrition Vol. XXXIV No. 3 (2019)

Table (9): Effect of diet containing untreated and treated pistachio, on lipid profile of healthy rats.

\begin{tabular}{|c|c|c|c|c|c|}
\hline \multicolumn{2}{|c|}{ Groups } & $\begin{array}{c}\text { Cholesterol } \\
\mathrm{mg} / \mathrm{dL}\end{array}$ & $\begin{array}{c}\text { Triacylglycerol } \\
\mathrm{mg} / \mathrm{dL}\end{array}$ & $\begin{array}{l}\mathrm{HDL}-\mathrm{c} \\
\mathrm{mg} / \mathrm{dL}\end{array}$ & $\begin{array}{l}\text { LDL-c } \\
\mathrm{mg} / \mathrm{dL}\end{array}$ \\
\hline \multirow{2}{*}{\multicolumn{2}{|c|}{ Basil diet }} & $139^{a b}$ & $79.33^{b}$ & $61.56^{a}$ & $61.57^{\mathrm{ab}}$ \\
\hline & & \pm 4.35 & \pm 17.18 & \pm 1.14 & \pm 7.10 \\
\hline \multicolumn{2}{|c|}{$\begin{array}{l}\text { Untreated } \\
\text { pistachio }\end{array}$} & $\begin{array}{l}138.33^{\mathrm{a}} \\
\pm 2.33\end{array}$ & $\begin{array}{l}151.00^{\mathrm{a}} \\
\pm 10.50\end{array}$ & $\begin{array}{l}62.32^{\mathrm{a}} \\
\pm 1.81\end{array}$ & $\begin{array}{l}48.48^{b} \\
\pm 11.10\end{array}$ \\
\hline \multirow{2}{*}{ 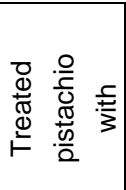 } & 6 kGy & $\begin{array}{r}135^{\mathrm{a}} \\
\pm 5.68\end{array}$ & $\begin{array}{l}112.33^{a} \\
\pm 29.31\end{array}$ & $\begin{array}{l}61.42^{\mathrm{a}} \\
\pm 1.43\end{array}$ & $\begin{array}{l}69.11^{\mathrm{a}} \\
\pm 6.40\end{array}$ \\
\hline & $\begin{array}{c}10 \\
\text { kGy }\end{array}$ & $\begin{array}{c}134.00^{\mathrm{ab}} \\
\pm 12.5\end{array}$ & $\begin{array}{l}178.50^{a} \\
\pm 39.50\end{array}$ & $\begin{array}{l}61.13^{a} \\
\pm 0.85\end{array}$ & $\begin{array}{l}51.66^{b} \\
\pm 21.25\end{array}$ \\
\hline
\end{tabular}

*Values are expressed as means \pm SD.

*Values at the same column with different letters are significant at $\mathrm{P}<0.05$.

Table (10): Effect of diet containing untreated and treated walnut on lipid profile of healthy rats.

\begin{tabular}{|c|c|c|c|c|c|}
\hline \multicolumn{2}{|c|}{ Groups } & $\begin{array}{c}\text { Cholesterol } \\
\mathrm{mg} / \mathrm{dL}\end{array}$ & $\begin{array}{c}\text { Triacylglycerol } \\
\mathrm{mg} / \mathrm{dL}\end{array}$ & $\begin{array}{l}\text { HDL-c } \\
\mathrm{mg} / \mathrm{dL}\end{array}$ & $\begin{array}{l}\text { LDL-c } \\
\mathrm{mg} / \mathrm{dL}\end{array}$ \\
\hline \multirow{2}{*}{\multicolumn{2}{|c|}{ Basil diet }} & $139.00^{\mathrm{b}}$ & $79.33^{b}$ & $61.56^{a}$ & $61.57^{c}$ \\
\hline & & \pm 4.3 & \pm 17.18 & \pm 1.14 & \pm 7.10 \\
\hline \multirow{2}{*}{\multicolumn{2}{|c|}{ Untreated walnut }} & $139.33^{b}$ & $151.33^{\mathrm{a}}$ & $58.33^{a}$ & $50.73^{b}$ \\
\hline & & \pm 8.08 & \pm 18.67 & \pm 3.61 & \pm 6.02 \\
\hline \multirow{4}{*}{ 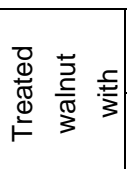 } & & $136.66^{\mathrm{ba}}$ & $170.66^{\mathrm{a}}$ & $58.90^{\mathrm{a}}$ & $44.63^{a}$ \\
\hline & 6 kGy & \pm 5.36 & \pm 6.43 & \pm 1.05 & \pm 6.27 \\
\hline & $10 k \mathrm{k}$ & $134.33^{\mathrm{a}}$ & $127.00^{\mathrm{a}}$ & $51.68^{\mathrm{a}}$ & $56.25^{\mathrm{ab}}$ \\
\hline & 10 KGy & \pm 5.33 & \pm 11.15 & \pm 5.11 & \pm 7.56 \\
\hline
\end{tabular}

*Values are expressed as means \pm SD.

*Values at the same column with different letters are significant at $\mathrm{P}<0.05$. 


\section{Ayat L. K. Soude; Hania F. G. El-Neily and Ashraf A. Abd El-Megeid}

Table (11): Effect of diet containing untreated and treated almond on malonaldehyed and antioxidant enzymes of healthy rats.

\begin{tabular}{|c|c|c|c|c|c|}
\hline \multicolumn{2}{|c|}{$\begin{array}{l}\text { Rarameters } \\
\text { Groups }\end{array}$} & $\begin{array}{c}\text { Malonaldehyed } \\
\mathrm{ng} / \mathrm{g} T\end{array}$ & $\begin{array}{l}\text { GPX } \\
\mathrm{U} / \mathrm{gT}\end{array}$ & $\begin{array}{c}\text { Catalase } \\
\mathrm{U} / \mathrm{gT}\end{array}$ & $\begin{array}{l}\text { SOD } \\
\mathrm{U} / \mathrm{gT}\end{array}$ \\
\hline \multicolumn{2}{|l|}{ Basil diet } & $\begin{array}{l}5.45^{\circ} \\
\pm 0.18\end{array}$ & $\begin{array}{l}64.87^{b} \\
\pm 0.49\end{array}$ & $\begin{array}{l}70.65^{b} \\
\pm 0.19\end{array}$ & $\begin{array}{l}20.59^{b} \\
\pm 0.07\end{array}$ \\
\hline \multicolumn{2}{|c|}{$\begin{array}{l}\text { Untreated } \\
\text { pistachio }\end{array}$} & $\begin{array}{l}3.90^{\mathrm{b}} \\
\pm 0.49\end{array}$ & $\begin{array}{l}{ }^{b} 66.06 \\
\pm 0.58\end{array}$ & $\begin{array}{l}86.48^{\mathrm{b}} \\
\pm 5.19\end{array}$ & $\begin{array}{l}21.46^{\mathrm{b}} \\
\pm 0.72\end{array}$ \\
\hline \multirow{2}{*}{ 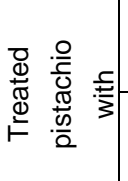 } & $\begin{array}{c}6 \\
\text { KGy }\end{array}$ & $\begin{array}{l}3.32^{\mathrm{b}} \\
\pm 0.30 \\
\end{array}$ & $\begin{array}{l}69.62^{\mathrm{a}} \\
\pm 0.75 \\
\end{array}$ & $\begin{array}{l}93.18^{\mathrm{a}} \\
\pm 0.75 \\
\end{array}$ & $\begin{array}{l}27.77^{2} \\
\pm 0.189 \\
\end{array}$ \\
\hline & $\begin{array}{c}10 \\
\text { KGy }\end{array}$ & $\begin{array}{l}2.18^{\mathrm{a}} \\
\pm 0.18\end{array}$ & $\begin{array}{l}\text { a } 69.29 \\
\pm 0.82\end{array}$ & $\begin{array}{l}94.68^{\mathrm{a}} \\
\pm 1.12\end{array}$ & $\begin{array}{l}27.46^{\circ} \\
\pm 1.23\end{array}$ \\
\hline
\end{tabular}

*Values are expressed as means \pm SD.

*Values at the same column with different letters are significant at $\mathrm{P}<0.05$.

Table (12): Effect of diet containing untreated and treated walnut on malonaldehyed and antioxidant enzymes of healthy rats.

\begin{tabular}{|c|c|c|c|c|c|}
\hline \multicolumn{2}{|c|}{ Groups } & $\begin{array}{c}\text { Malonaldehyed } \\
\mathrm{ng} / \mathrm{g} T\end{array}$ & $\begin{array}{l}\text { GPX } \\
\text { U/gT }\end{array}$ & $\begin{array}{c}\text { Catalase } \\
\mathrm{U} / \mathrm{gT}\end{array}$ & $\begin{array}{l}\text { SOD } \\
U / g T\end{array}$ \\
\hline \multicolumn{2}{|c|}{ Basil diet } & $\begin{array}{l}5.45^{\mathrm{a}} \\
\pm 0.18\end{array}$ & $\begin{array}{c}64.87^{\mathrm{bc}} \\
\pm 0.49\end{array}$ & $\begin{array}{l}70.65^{c} \\
\pm 0.19\end{array}$ & $\begin{array}{r}20.59^{b} \\
\pm 0.07\end{array}$ \\
\hline \multicolumn{2}{|c|}{ Untreated walnut } & $\begin{array}{l}3.90^{b} \\
\pm 0.49\end{array}$ & $\begin{array}{l}64.48^{c} \\
\pm 1.09\end{array}$ & $\begin{array}{l}82.42^{b} \\
\pm 0.93\end{array}$ & $\begin{array}{l}21.31^{\mathrm{b}} \\
\pm 0.63\end{array}$ \\
\hline \multirow{2}{*}{ 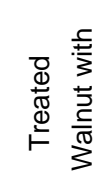 } & 6 KGy & $\begin{array}{l}4.10^{b} \\
\pm 0.60\end{array}$ & $\begin{array}{c}67.37^{\mathrm{ab}} \\
\pm 0.56\end{array}$ & $\begin{array}{l}98.01^{\mathrm{a}} \\
\pm 1.57\end{array}$ & $\begin{array}{l}29.06^{\mathrm{a}} \\
\pm 0.37\end{array}$ \\
\hline & $\begin{array}{c}10 \\
\text { KGy }\end{array}$ & $\begin{array}{l}4.01^{b} \\
\pm 1.05\end{array}$ & $\begin{array}{l}68.84^{a} \\
\pm 0.86\end{array}$ & $\begin{array}{l}99.98^{a} \\
\pm 0.46\end{array}$ & $\begin{array}{l}26.07^{a} \\
\pm 3.92\end{array}$ \\
\hline
\end{tabular}

${ }^{*}$ Values are expressed as means \pm SD.

*Values at the same column with different letters are significant at $\mathrm{P}<0.05$ 
Egyptian J. of Nutrition Vol. XXXIV No. 3 (2019)

\section{References}

Aebi H. (1984):

Determination of Catalase.MethodEnzymol 105, 121-126.

Ali, A.; Mohsen, B. and Mohammad, A. S. (2018):

Effect of gamma irradiation on the extraction yield, antioxidant, and antityrosinase activities of pistachio green hull extract. Radiation Physics and Chemistry 144.373-378.

Antonio, AL.; Carocho, M.; Bento, A.; Quintana, B.; Luisa Botelho, M. and Ferreira, I.C. (2012):

Effects of gamma radiation on the biological, physicochemical, nutritional and antioxidant parameters of chestnutsA review. Food ChemToxicol; 50:3234-3242.

A.O.A.C. (2003):

Association of Official Analytical Chemists International $18^{\text {th }}$ ed., Arlington, Virginia, USA.

Aronis, K.N.; Vamvinia, M.T. and Chamberlanda, J.P. (2012):

Short-term walnut consumption increases circulating total adiponectin and apolipoprotein A concentrations, but does not affect markers of inflammation or vascular injury in obese humans with the metabolic syndrome: data from a doubleblinded, randomized, placebo-controlled study. Metabolism 61: 577-582. 


\section{Ayat L. K. Soude; Hania F. G. El-Neily and Ashraf A. Abd El-Megeid}

Bao, Y.; Han, J.; Hu, F.B.; Giovannucci, E.L.; Stampfer, M.J. and Willett, W,C. (2013):

Association of nut consumption with total and cause-specific mortality. New English Journal of Medicine.;369(21):2001-11.

Bedia, B.; Ismail, C.; and Abdulahad, D. (2015):

Determination of Hepatoprotective and Antioxidant Role of Walnuts Against Ethanol-Induced Oxidative Stress in Rats.CellBiochemBiophys .71:1191-1198.

Behgar, M.; Ghasemi, S.; Naserian, A.; Borzoie, A. andFatollahi, H. (2011):

Gamma radiation effects on phenolics, antioxidants activity and in vitro digestion of pistachio (Pistachiavera) hull. RadiatPhysics Chemistry;80:963-967.

Boateng, J.; Willis, S.; Busambwa, K.; Shackelford, L. and Verghese, M. (2016):

Modifying Effects of Pistachio Nuts on Antioxidant Enzymes in Azoxymethane (AOM) - induced Formation of Aberrant Crypt Foci. international journal of cancerRecearch. 12 (3-4):140151.

Dacia, J.V. and Lewis S.M. (1985):

Practical Haematology. Churchill, Livingstone, ED. binburgh, London and NY, 5th ed. 
Egyptian J. of Nutrition Vol. XXXIV No. 3 (2019)

Damasceno, N.R.; Perez-Heras, A. and Serra, M. (2011):

Crossover study of diets enriched with virgin olive oil, walnuts or almonds. Effects on lipids and other cardiovascular risk markers. Nutrition Metabolism. Cardiovascular. Diseases. 21: 14-20.

Dandan, S.; Chaoyin, C.; Shenglan, Z.; Feng, G.; Diqiu, L. and Hao, S. (2014):

Effects of Walnut Polyphenol on Learning and Memory Functions in Hypercholesterolemia MiceJournal of Food and Nutrition Research, 2(8): 450-456.

Diehl, F. (1981):

Effects of combination processes on the nutritive value of food. Combination Processes in the Food Irradiation. International Atomic Agency, Vienna, Austria. pp. 349-366.

Duncan, D. B. (1955):

Multiple range test and multiple F-test. Biometrica 11:1.

Farkas, J. and Mohacs-Farkas C. (2011):

History and future of food irradiation. Trends Food ScienceTechnolgy. 22:121-126.

Ferhad, M. ; Ibrahim, O. H.; Kenan, Y. and Hudai, Y. (2010):

Some chemical composition of walnut (JuglansregiaL.) selections from Eastern Turkey.African Journal of Agricultural Research 5 (17): 2379-2385. 


\section{Ayat L. K. Soude; Hania F. G. El-Neily and Ashraf A. Abd El-Megeid}

Firdewald, W.T. (1972):

Estemation of concentration of Iwo-denisty lipoprotein cholesterol in plasma, without use of preparative ultracentrifuge. Clinical Chemistry. 18 (6):499-502.

Hamilton, R. J. and Hamilton, S. (1993):

Lipid Analysis a Practical Approach. IRL press, Oxford University Press, Oxford.

Han, J.M.; Jo, A.N.; Lee, S.M.; Bae, H.S.; Jun, D.W. and Cho, Y.K. (2014):

Associations between intakes of individual nutrients or whole food groups and non-alcoholic fatty liver disease among Korean adults. Journal of Gastroenterol Hepatol.; 29(6):126572.

Hegested, D.M.; Mills, C.; Elvehjem, C.A. and Hart, E.B. (1941):

Choline in the nutrition of the chicks. Journal ofBiological Chemistry., 138:459-470.

Heidemann, C.; Sun, Q. and van Dam, R.M. (2008).

Total and high-molecular-weight adiponectin and resistin in relation to the risk for type 2 diabetes in women. Ann Intern Med 149: 307-316. 
Egyptian J. of Nutrition Vol. XXXIV No. 3 (2019)

Jacki, M. Rorabaugh; Ajay, P.S.; Isabel, M.S.; Michelle, R.F.; Nicholi, V.; Peter, F.; Christopher, M.; Margaret, A.M. and Ted, W.(2011):

English and Black Walnut Phenolic Antioxidant Activity in Vitro and Following Human Nut Consumption. Food and Nutrition Sciences, 2, 193-200.

Jiang, R.; Manson, J.E.; Stampfer, M.J.; Liu, S.; Willett, W.C. and Hu, F.B. (2002):

Nut and peanut butter consumption and risk of type 2 diabetes in women. Journal of the American Medical Association.; 288(20):2554-2560.

Kamazani, N.A.; Mortazavi, S.A.; Ebrahimi, M.T.; Hasani, M. and Ghotbi, M. (2015):

The Effect of Different Solvent Systems on Some Chemical Properties of Pistachio Nut Oil Contaminated with Aflatoxin. Journal of Food Biosciences and Technology, Islamic Azad University, Science and Research Branch, 5(1): 1-12.

Kashani, M. N.; Tabil, L. G.; Mortazavi, A.; Safe, A. K., Nakhaei, M. and Nikkho, M.(2008):

Effect of Drying Methods on Quality of Pistachio Nuts. An ASAE /CSAE Meeting Presentation. September 27-28.

Kochar, J.; Gaziano, J.M.and Djoussé, L. (2010):

Nut Consumption and Risk of Type 2 Diabetes in the Physicians' Health Study. European Journal of Clinical Nutrition64: 75-79. 


\section{Ayat L. K. Soude; Hania F. G. El-Neily and Ashraf A. Abd El-Megeid}

Konya, E.; Bujdosoc, G.; BERKI, M.; Nagy-Gasztony, M. and Adany, N. (2015):

Effect of short- term storage on walnut fruit quality.ActaAlimentaria, 44 (4): 601-608.

Maclaughlin, W.L.; Wenixu, C.; Jai, H. and Humphreys, J. C. (1985):

Responseofradiochromic film dosimeter to gamma rays in different atmospheres. RadiationPhysics and Chemistry 25 (46): 793-805.

Mahfouz AL-Bachier (2014):

Microbiological, sensorial and chemical quality of gamma irradiated pistachio nut (PistaciaVera L.). The Annals of the University Dunarea de Jos of Galati Fascicle VI - Food Technology 38(2): 57-68.

McKiernan, F.;Lokko, P. and Kuevi, A. (2010):

Effects of peanut processing on body weight and fasting plasma lipids. British Journal of Nutrition 104: 418-426.

Miltiadis, V.C. and Eleni, T. (2015):

Oil composition in stored walnut cultivars-quality and nutritional value. European Journal of LipidScince. Technol.117: 338-348. 
Egyptian J. of Nutrition Vol. XXXIV No. 3 (2019)

Naziroglu, M.; Cay, M.; Ustündag, B.; Aksakal, M. and Yekeler, H. (1999):

Protective effects of vitamin E on carbon tetrachloride-induced liver damage in rats. Cell Biochemistry and Function;17 (4): 253-259.

Nishikimi, M.; Roa, N.A. and Yogi (1972):

Determination of Superoxide dismutases (SODs). Biochemical and BiophysicalResearch Communications., 46: 849-854.

Nur, A.;Mehmet, A.;Cahit, B.;Serdare, G. H.;Hakim, C.;Emine, M. H.;Abdullah, Y.;Memet, T.;Serdar, S.;Ibrahim. S.andVedat, D. (2007):

Pistachio Intake Increases High Density Lipoprotein Levels and Inhibits Low-Density Lipoprotein Oxidation in Rats. The tohoku journal of experimental medicine., 212: 43-48.

Paglia, D. E. and Valentine, W. N. (1967): Journal of Laboratory and Clinical Medicine. 70:158-169.

Pan, A. Sun and Manson, J.E. Q. (2013).

Walnut Consumption Is Associated with Lower Risk of Type 2 Diabetes in Women. Journal of Nutrition.143: 512-518.

Reeves, P. G.; Nielsen, F.H. and fahmy, G.C. (1993):

AIN - 93 purified diets for laboratory rodents: Final report of the American Institute of Nutrition writing committee on the reformulation of the AIN-76A rodent diet. Journal of Nutrition., 123 (11):1939-1951. 


\section{Ayat L. K. Soude; Hania F. G. El-Neily and Ashraf A. Abd El-Megeid}

Reis, C.E.G.; Ribeiro, D.N. and Costa, N.M.B. (2012)

Acute an second-meal effects opeanuts on glycaemic response an appetite in obese women with high type 2 diabetes risk: a randomised crossover clinical trial. British Journal of Nutrition. 109: 2015-2023.

Richmond, W. (1973):

preparation and properties of cholesterol oxidase from nacrodiasp.and its application to enzyme assay of total cholesterol in serum .Clinical Chemistry.19:1350-1355.

Sabate, J.; Haddad, E. andTanzman, J.S. (2003):

Serum lipid response to the graduated enrichment of a Step I diet with almonds: a randomized feeding trial. Clinical Chemistry 77: 1379-1384.

Sari, I. B. Y. and Bagci, C. (2010):

Effect of pistachio diet on lipid parameters, endothelial function, inflammation, and oxidative status: A prospective study. Nutrition. 26 (4): 399-404.

Stamatios, F. M. and Michael, G. K. (2009):

Effect of C-irradiation on the physicochemical and sensory properties of walnuts (Juglansregia L.). European Food Rescearch and Technology. 228:823-831.

Stein, E. A. (1987):

Lipids, lipoprptien and apolipoprotein. In: NW Tietz,ed. Philadelhia: WB saunders, $448-481$. 
Egyptian J. of Nutrition Vol. XXXIV No. 3 (2019)

Sza-Tao, K.W.C. and Sathe, S.K. (2000):

Walnut (JuglansregiaL): proximate composition, protein solubility, protein amino acid composition and protein in vitro digestibility. Journal Science and Food Agricultural, 80:13931401.

Tey, S.L.; Brown, R.C. and Chisholm, A.W. (2011):

Effects of different forms of hazelnuts on blood lipids and $\alpha$ tocopherol concentrations in mildly hypercholesterolemic individuals. European Journal of Clinical Nutrition.65: 116124.

Tomaino, A.; Martorana, M.; Arcoraci, T.; Monteleone, D.; Giovinazzo, C. and Saija, A. (2010):

Antioxidant activity and phenolic profile of pistachio (Pistaciavera L., variety Bronte) seeds and skins. Journal of Biochemistry 92, 1115-1122.

Umit, G. N.; Tuncay, G.; Murat, T.; Orhan, D. and Muhammet, A. (2011):

Determination of fatty acid composition of $\mathrm{Y}$-irradiated hazelnuts, walnuts, almonds, and pistachios. Radiation Physics and Chemistry80: 578-581.

Vassilia, J. S.; Irini, F. S.; Katerina, K.; Dimitra, L.; Constantinos, M. and Panagiotis, Z. (2015):

GC-FID and NMR Spectroscopic Studies on Gamma Irradiated Walnut Lipids.Journal of Spectroscopy.1-10. 


\section{Ayat L. K. Soude; Hania F. G. El-Neily and Ashraf A. Abd El-Megeid}

Xiaoying, M. and Yufei, H.(2012):

Composition, Structure and Functional Properties of Protein Concentrates and Isolates Produced from Walnut (JuglansregiaL.).International Journal of Molecular Sciences13: 1561-1581.

\section{Young, D. S.(1990):}

Effect of drugs on clinical laboratory test. $3^{\text {th }}$ ed $3: 6-12$.

Young, D.S.(2001):

Effect of disease on clinical Lab. Tests, $4^{\text {th }}$ ed 4: 3-9. 
Egyptian J. of Nutrition Vol. XXXIV No. 3 (2019)

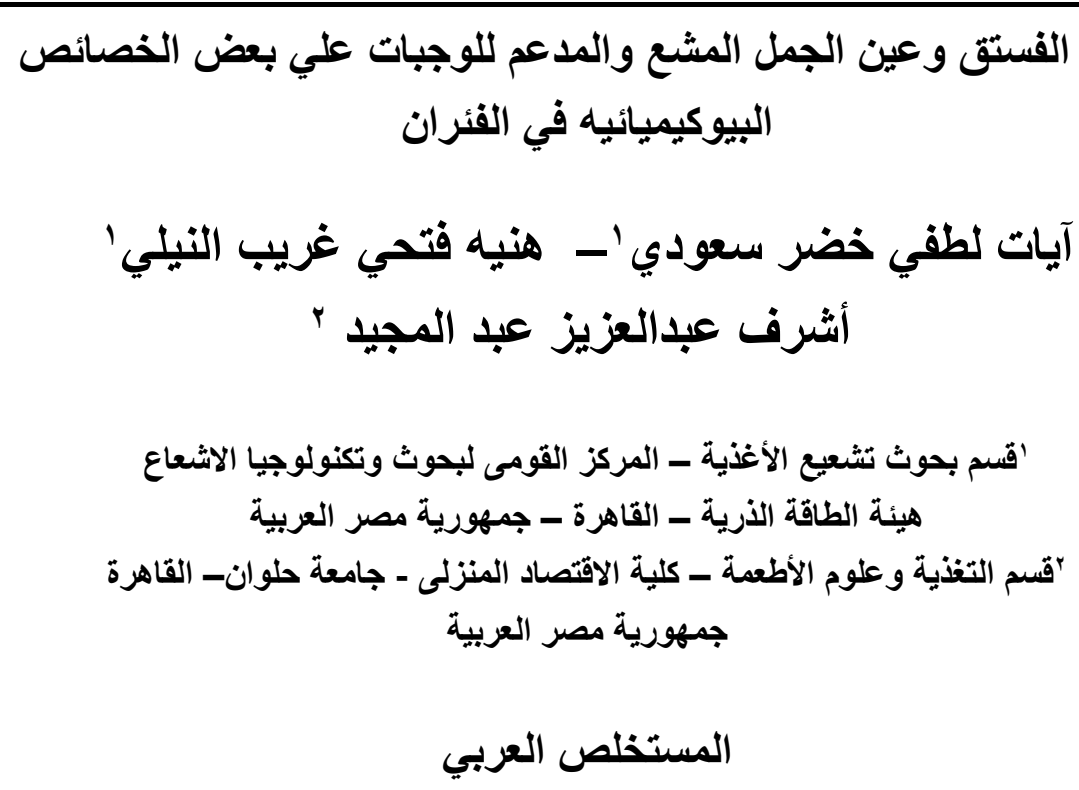

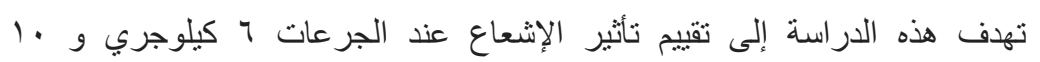

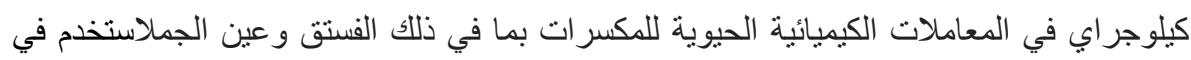

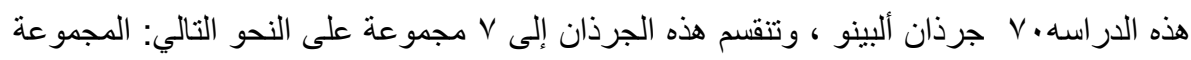

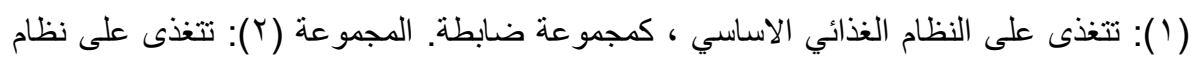

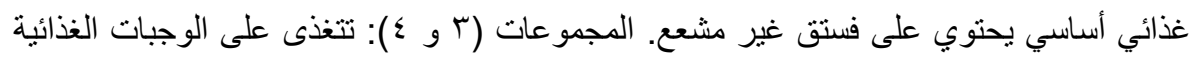

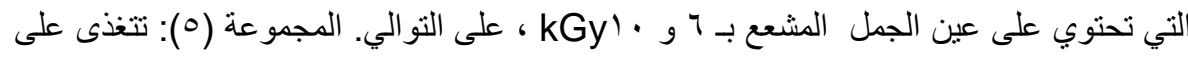

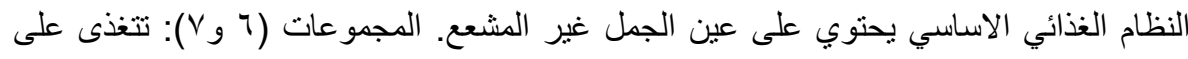

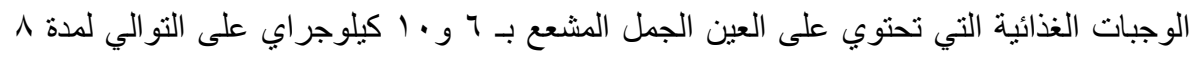
أسابيع.

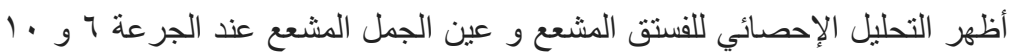

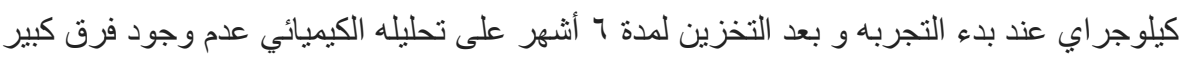

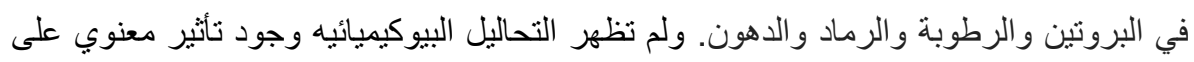

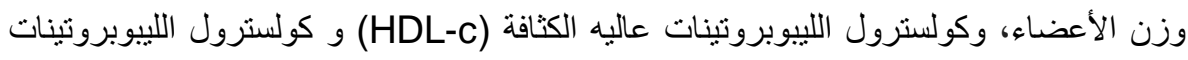

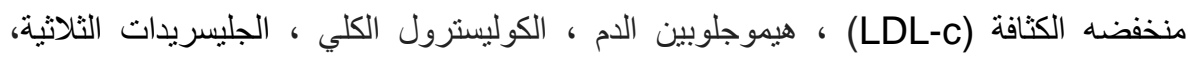

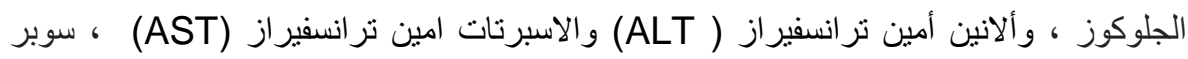




\section{Ayat L. K. Soude; Hania F. G. El-Neily}

\section{and Ashraf A. Abd El-Megeid}

اوكسيد ديسموتيز(SOD) ، جلوتاثيون بيروكسيديزوكاتالز الكبد في مجموعات عينات الفستق

وعين الجمل غير المشعع أو المشعٌّ ، عند مقارنتها مع المجموعه الضابطه التي تنغذى على التى النظام

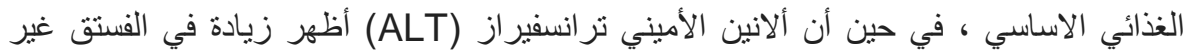

المعالج وكانت هناك زيادة كبيرة في إنزيمات مضادات الأكسدة في جميع العينات. 